\title{
Kompetencje nauczyciela wobec wyzwań tanatopedagogicznych
}

Student każdego kierunku nauczycielskiego przygotowuje się do wzięcia odpowiedzialności za osiągnięcia uczniów oraz ich funkcjonowanie we współczesnym społeczeństwie ${ }^{1}$. By tak się stało, musi on sprostać wyzwaniom, które pojawiają się we współczesnej edukacji. Obszarami edukacyjnymi, wymagającymi szczególnej wiedzy, umiejętności i wrażliwości są choroba i śmierć. Gdy występują one w środowisku szkolnym, stają się trudnym wyzwaniem egzystencjalnym i edukacyjnym.

Wyzwanie to wiąże się z wieloma trudnościami, m.in. z tabuizacją śmierci oraz izolacją społeczną osób chorych. Aby przeciwdziałać tym zjawiskom, podejmowane są inicjatywy o charakterze społecznym, czego przykładem może być działalność hospicjów, która w ostatnich latach wprowadziła tematykę choroby i śmierci do przestrzeni medialnej. Przyczyniło się to w pewnym stopniu do poprawy stanu świadomości społecznej. Działania te nie są jednak wystarczające. Potrzebne jest oddziaływanie edukacyjne prowadzone przez szkoły, w głównej mierze przez nauczycieli i pedagogów posiadających stosowne kompetencje. Dzięki nim nieuniknione doświadczenia życiowe stają się dla uczniów

1 M. Konieczna-Kucharska, Miękkie i twarde kompetencje nauczycieli, „Zeszyty Naukowe Politechniki Częstochowskiej - Zarządzanie” 2015, nr 19, s. 229. 
bardziej zrozumiałe, a społeczność szkolna otrzymuje wsparcie ze strony edukatorów. W tym celu niezbędne jest uwzględnienie wątków tanatycznych w kształceniu nauczycieli. Dzięki temu będą oni wyposażeni w stosowne kompetencje, a młodzi ludzie będą lepiej przygotowani do życia.

\section{Wyzwania edukacyjne i kompetencje nauczycieli}

Zbigniew Kwiasowski określa wyzwania edukacyjne jako trudne, skomplikowane sytuacje, którym trzeba w danym momencie sprostać. Często zalicza się do nich deprecjację instytucji szkoły, ignorancję i niekompetencję władz oświatowych, częściowo niekontrolowany „boom” informatyczny, postępującą brutalizację i pauperyzację życia, szybko rozszerzające się spektrum zagrożeń współczesnego człowieka oraz kryzys zaufania i więzi społecznej². Tłem współczesnych wyzwań edukacyjnych są podstawowe pytania, kim jest człowiek, co jest wartością, jaki jest fundament, cel i sens wychowania ${ }^{3}$. Poszukiwanie odpowiedzi na nie jest zadaniem, które wykracza poza obszar edukacji, ale jednocześnie znajduje w niej ważne wyjaśnienie.

Chcąc sprostać wyzwaniom, należy posiadać i rozwijać stosowne kompetencje. W szerokim ujęciu kompetencje są to podstawowe wymagania w zakresie umiejętności, wiadomości i cech psychofizycznych, które umożliwiają efektywne wykonywanie charakterystycznych zadań zawodowych. Źródłosłów tego pojęcia (łac. competentia - odpowiedzialność, zgodność, uprawnienie do działania) wskazuje również na odpowiedzialność za ich zdobycie i realizację․ Cechą wspólną licznych definicji kompetencji nauczycielskich są trzy zasadnicze

$2 \quad$ Z. Kwiasowski, K. Cenda-Miedzińska (red.), Edukacja dla bezpieczeństwa wobec wyzwań współczesności, Wydawnictwo Uniwersytetu Pedagogicznego w Krakowie, Kraków 2012, s. 12.

3 S. Košč, Pedagogika wobec wyzwań współczesności. Człowiek - wartości-wychowanie, [w:] E. Włodek, A. Mirski (red.), Pedagogika wobec wyzwań współczesności. Człowiek - wartości - wychowanie, Wydawnictwo Akademia Ignatianum w Krakowie, Kraków 2016, s. 14.

4 W. Okon', Nowy słownik pedagogiczny, Wydawnictwo Akademickie Żak, Warszawa 2004, s. 185. 
elementy: wiedza, umiejętności praktyczne oraz określone specyficzne cechy osobowościowe, wskazane i oczekiwane w pracy nauczyciela ${ }^{5}$.

Maria Czerpaniak-Walczak podkreśla, że:

kompetencja nie jest skończonym rezultatem, lecz teoretycznym celem, który stanowi podstawę rozwoju osoby i zmiany w jej świecie życia. Umożliwia bowiem dostrzeganie i wyjaśnianie poszczególnych zjawisk oraz świadome i odpowiedzialne zachowanie wobec nich. W takim znaczeniu stanowi raczej element koncepcji afirmujących autonomię osoby, niż tych, które skupiają się na identyfikacji z założonym z góry zestawem wzorów i treści ludzkich zachowań. Taka perspektywa wydaje mi się być szczególnie użyteczna w rozważaniach nad edukacją ${ }^{6}$.

Podstawowymi elementami kompetencji edukacyjnych są wiedza i sprawności, ale kompetencje wykraczają poza zakres wiedzy proceduralnej. Jak zauważa Wacław Strykowski, „charakterystyczną cechą kompetencji jest jej podmiotowy charakter. Kompetencje są własnością określonej osoby. Szczególnym zaś atrybutem kompetencji jest dynamika ujawniająca się w działaniu, w relacji człowieka z rzeczywistością"7. Uwzględnienie podmiotowego charakteru kompetencji, ich dynamiki oraz szerokich perspektyw rozwoju pozwala żywić nadzieję, iż w obliczu szczególnie trudnych wyzwań edukacyjnych kompetencje nauczycieli i pedagogów okażą się wystarczające, by sprostać pojawiającym się wyzwaniom. Należy także zwrócić uwagę na podział kompetencji na miękkie (behawioralne) i twarde (funkcjonalne). Pierwsze odnoszą się do umiejętności osobistych, cech charakteru, sposobu postrzegania otoczenia i podejmowania działań. Kompetencje twarde wyrażają się natomiast w posiadanej wiedzy, umiejętnościach i kwalifikacjach nabytych w procesie edukacji ${ }^{8}$.

Można wymienić następujące obszary kompetencji nauczycielskich: merytoryczne, psychologiczno-pedagogiczne, diagnostyczne, planistyczne, projektowe, dydaktyczno-metodyczne, komunikacyjne, medialne, kontrolne, ewaluacyjne, oceniania programów i podręczników,

$5 \quad$ I. Żeber-Dzikowska, M. Wysocka-Kunisz, A. Szydłowska, Kompetencje nauczyciela w kontekście kształcenia, „Społeczeństwo. Edukacja. Język” 2016, nr 4, s. 95.

6 M. Czerepaniak-Walczak, Kompetencja: słowo kluczowe czy „wytrych” w edukacji, „Neodidagmata” 1999, nr 24, s. 59.

7 W. Strykowski, Kompetencje współczesnego nauczyciela, „Neodidagmata” 2005, nr 27/28, s. 17.

8 M. Konieczna-Kucharska, Miękkie i twarde..., s. 231. 
autoedukacyjne $^{9}$. Z kolei podstawę klasyfikacji kompetencji nauczycielskich, proponowaną przez Roberta Kwaśnicę, stanowi koncepcja dwóch racjonalności. Według niej doświadczenie ludzkie powstaje na bazie wiedzy praktyczno-moralnej i wiedzy technicznej. W oparciu o te założenia autor wyodrębnia dwie grupy kompetencji: praktyczno-moralne i techniczne. Pierwsza grupa, nadrzędna wobec drugiej, obejmuje kompetencje moralne, interpretacyjne i komunikacyjne, pozwalające postrzegać świat i drugiego człowieka jako rzeczywistość wymagającą ciągłej interpretacji oraz bycia w dialogu z innymi i z samym sobą. Kompetencje techniczne obejmują kompetencje normatywne, metodyczne i realizacyjne. Pozwalają one na osiąganie zamierzonych celów edukacyjnych ${ }^{10}$. Jeszcze inną typologię proponuje Janusz Mastalski. Obejmuje ona następujące obszary kompetencji: przedmiotowe, dydaktyczne, komunikacyjne, wychowawcze i społeczne oraz moralne ${ }^{11}$. Wydaje się, że krótka analiza diady „wyzwania - kompetencje” ukazała zawartą w niej dynamikę, a także potrzebę głębszego wglądu w sytuację tanatyczną oraz oczekiwane kompetencje nauczycielskie.

\section{Tanatyczne wyzwania edukacyjne}

Choroba i śmierć stoją w pozornej sprzeczności z założeniami szkolnej edukacji. Wszak jej celem jest rozwój ucznia, a nie jego śmierć. Dlatego w programach nauczania i praktyce wychowawczej tematyka śmierci pojawia się rzadko ${ }^{12}$. Tymczasem statystyki dotyczące śmiertelności wśród dzieci oraz praktyka wychowawcza pokazują że środowisko szkolne nie jest wolne od tych dramatycznych doświadczeńn ${ }^{13}$.

$9 \quad$ W. Strykowski, Kompetencje..., s. 18-27.

10 R. Kwaśnica, Wprowadzenie do myślenia o nauczycielu, [w:] Z. Kwieciński, B. Śliwerski (red.), Pedagogika. Podręcznik akademicki, t. 2, PWN, Warszawa 2004, s. 300-301.

11 J. Mastalski, Aksjologiczne wymiary kompetencji nauczyciela w kontekście wspótczesnych wyzwań cywilizacyjnych, [w:] J. Grzesiak (red.), Ewaluacje i innowacje $w$ edukacji. Kompetencje i odpowiedzialność nauczyciela, Uniwersytet im. Adama Mickiewicza w Poznaniu i Państwowa Wyższa Szkoła Zawodowa w Koninie, Kalisz - Konin 2010, s. 44-45.

12 M. Piorunek, I. Werner, (Nie)wspierajacy wychowawca klasy. Realizacja pomocowych aspektów roli nauczyciela z perspektywy gimnazjalistów, [w:] S.T. Kwiatkowski, D. Walczak (red.), Kompetencje interpersonalne w procesie edukacji, Wydawnictwo Akademii Pedagogiki Specjalnej, Warszawa 2017, s. 234.

13 Mimo iż współczesna medycyna ratuje w sposób trwały życie ponad 80\% chorych dzieci, ich zachorowania i śmiertelność wciąż pozostają istotnym problemem. 
Oprócz śmierci ucznia, doświadczenia te obejmują odejścia członków rodzin uczniów, a także pracowników szkoły, co nie pozostaje bez wpływu na funkcjonowanie psychospołeczne dziecka czy młodego człowieka. Środowisko szkolne nie zawsze potrafi sprostać temu niezwykle trudnemu wyzwaniu. Warto zaznaczyć, iż „sprostać” nie oznacza w tym przypadku „poradzić sobie” z problematyką cierpienia i śmierci, gdyż przerasta ona możliwości percepcyjne, doświadczenie i potencjał człowieka. Jest to szczególnie widoczne w przypadku śmierci dziecka, postrzeganej jako śmierć niezawiniona ${ }^{14}$. Chodzi tu raczej o przeciwdziałanie destrukcyjnym psychospołecznym skutkom choroby i śmierci w takim zakresie, w jakim jest to możliwe.

Utrudnieniem w realizacji tego zadania jest brak należytej uwagi poświęcanej temu zagadnieniu w procesie edukacji. Brak ten widoczny w środowisku uczniów i nauczycieli jest odzwierciedleniem stanu wiedzy i świadomości społeczeństwa. Nieprzypadkowo coraz częściej mówi się o zjawisku tabuizacji śmierci, które wyraża się w izolacji społeczeństwa od problematyki śmierci i choroby: „Umierający zostaje przeniesiony do szpitala, ponieważ nie powinien swoją obecnością niepokoić otoczenia, które za cel stawia sobie zapomnienie o istnieniu śmierci" ${ }^{15}$. Owa tabuizacja przybiera różne formy, znacznie wykraczając poza problem jej medykalizacji. Jak zauważa Ilona Zakowicz, w drugiej połowie XX wieku śmierć zaczęła być postrzegana

jako pewnego rodzaju nieprzyzwoitość, śmierć stała się jedną z najbardziej pożądanych atrakcji medialnych i jednocześnie źródłem niewyczerpanych wręcz zasobów wyobrażeń, które przyczyniły się do wykrystalizowania nowego obrazu śmierci. Potwierdzeniem tej tezy jest niegasnące zainteresowanie tematami tanatycznymi w mediach, wyrażające się przez epatowanie obrazami śmierci nagłej, wyreżyserowanej i odległej. Śmierci bezpiecznej, bo oglądanej poniekąd „za szybą", zbyt odrealnionej i obcej, by mogła dotyczyć życzących ${ }^{16}$.

A. Baruch, Choroba nowotworowa dziecka jako czynnik powodujący zmiany $w$ funkcjonowaniu rodziny - wybrane aspekty, „Przegląd Pedagogiczny” 2013, nr 2, s. 133.

14 G. Godawa, Rodzina wobec nieuleczalnej choroby dziecka. Aspekty tanatopedagogiczne, Oficyna Wydawnicza „Impuls”, Kraków 2018, s. 1621.

15 A. Kwiecińska, Wybrane zagadnienia z tanatologii, [w:] K. de Walden-Gałuszko, A. Kaptacz (red.), Pielęgniarstwo w opiece paliatywnej i hospicyjnej, PZWL, Warszawa 2008, s. 250.

16 I. Zakowicz, Tanatyczny tryptyk ponowoczesności: kryzys, pornografia i renesans śmierci, „Ogrody Nauk i Sztuk” 2011, nr 1, s. 61. 
Ów redukcjonizm sprawia, że społeczeństwo często nie jest wystarczająco przygotowane, by dobrze przeżyć ostatni okres życia, a także, by towarzyszyć innym w odchodzeniu. Dlatego środowisko szkolne nie zawsze potrafi sprostać wyzwaniu, jakim jest choroba i śmierć dziecka, członka rodziny czy nauczyciela.

Krystyna Ablewicz podkreśla, jak ważną rolę w kształceniu tanatologicznym pełnią nauczyciele, a jednocześnie trafnie diagnozuje trudności, jakie napotykają. Obszar ten

należy do niszowego w pedagogicznych badaniach, refleksjach czy praktyce. Wymaga od pedagoga dużej wrażliwości, taktu i subtelności, empatii i emocjonalnego zrównoważenia. Nie mając bowiem w miarę uporządkowanej dla samego siebie tej sfery egzystencjalnych doświadczeń, łatwo można popełnić pedagogiczny grzech moralizowania lub unieważniania trudnych i wzajem się przenikających przeżyć takich jak: smutek, rozpacz, niepokój, złość, bunt, nadzieja, ulga, spokój, jak potrzeba współczucia oraz zaopiekowania, i jednocześnie odosobnienia i poczucia samotności w przeżywaniu żałoby. A jest on i dla dorosłego trudny, może i dlatego, że raczej w jego wychowaniu zaniedbany ${ }^{17}$.

Przytoczona wypowiedź wskazuje na potrzebę nabywania przez nauczycieli kompetencji niezbędnych do podejmowania wyzwań w środowisku szkolnym. Analiza tych kompetencji pozwoli na zaproponowanie działań zmierzających do poprawy stanu rzeczy.

\section{Kształtowanie kompetencji tanatopedagogicznych}

Postulat kształtowania kompetencji nauczycieli niezbędnych w szkolnych sytuacjach związanych ze śmiercią zawiera się w zakresie tanatopedagogiki. Tanatopedagogika to nowo powstała subdyscyplina pedagogiczna, której celem jest

„wychowanie do cierpienia i śmierci” będące w istocie rzeczy wychowaniem do życia (...). Jest to w istocie wychowanie do świadomego życia i (wespół) życia z tymi, którzy chorują, cierpią i prędzej czy później umrą, ale trudno powiedzieć, kiedy to nastąpi. Podstawę tej sfery wychowania stanowi więc idea nieustannej dbałości

$17 \quad$ K. Ablewicz, Recenzja rozprawy doktorskiej p. mgr Justyny Sztobryn-Bochomulskiej pt.: Tanatos w literaturze dziecięcej i jego pedagogiczny wymiar (295 s.) napisanej pod kierunkiem dr hab. prof. UŁ Anny Walczak, http://wnow.uni.lodz.pl/wp-content/ doc/doktoraty/Recenzja2_JustynaSztobryn.pdf (dostęp: 30.08.2019). 
o życie i poprawiania jego jakości w każdych okolicznościach - niejako mimo wszystko ${ }^{18}$.

Ujęcie zagadnienia wychowania człowieka z uwzględnieniem jego śmiertelności tylko pozornie nadaje tanatopedagogice pesymistyczny wydźwięk. W rzeczywistości to połączenie jest w pełni uzasadnione, a nawet wskazane, gdyż konfrontacja ze śmiercią nie przekreśla myślenia o życiu, szczęściu i rozwoju. Uznanie realizmu życia i śmierci jest podstawowym wymogiem wychowawczym i należy ono do niepodważalnych prawd ludzkiej egzystencji ${ }^{19}$. Głęboka refleksja nad wychowaniem i śmiercią wyposaża ucznia w narzędzia ułatwiające percepcję śmierci oraz wzmacnia jego dążenie do samorealizacji i osiągnięcia poczucia spełnienia.

Wychowanie uczniów do konfrontacji z cierpieniem i śmiercią, dokonujące się w środowisku szkolnym, winno wyrażać się w programach edukacyjnych, uwzględniających idee tanatopedagogiczne. Takie działania wymagają wsparcia ze strony nauczycieli, co z kolei jest uwarunkowane posiadaniem określonych kompetencji tanatopedagogicznych, gdyż odpowiednie kształcenie osób mających udzielać wsparcia w cierpieniu jest niezwykle istotne ${ }^{20}$.

Problematyka kształcenia tanatopedagogicznego na poziomie uniwersyteckim stała się przedmiotem rozważań autorów, spośród których należy wymienić Przemysława Pawła Grzybowskiego ${ }^{21}$ oraz Ewę Nierobę, Ireneusza Zawłockiego i Krzysztofa Niewiadomskiego ${ }^{22}$. Pierwszy z wymienionych autorów, zwraca uwagę, że przyjęcie założeń tanatopedagogicznych w pedeutologii pozwala na ustalenie zakresu treści kształcenia nauczycieli dotyczącego edukacji tanatologicznej

18 P.P. Grzybowski, Chorzy i umierający jako Obcy. Wspólne wątki pedagogiki międzykulturowej i tanatopedagogiki, [w:] T. Lewowicki, E. Ogrodzka-Mazur (red.), Edukacja międzykulturowa-teorie, poglądy, doświadczenia społeczne, Wydawnictwo Adam Marszałek, Cieszyn - Warszawa - Toruń 2010, s. 291-292.

19 E. Nieroba, I. Zawłocki, K. Niewiadomski, Tanatopedagogika w procesie kształcenia nauczycieli, „Edukacja-Technika-Informatyka” 2010, nr 1, s. 253.

20 G. Godawa, Funkcjonowanie rodziny dziecka objętego domowa opieka hospicyjna. Studium tanatopedagogiczne, Wydawnictwo Akapit, Toruń 2016, s. 26.

21 P.P. Grzybowski, Praktyczne cele $i$ aspekty kształcenia tanatologicznego pedagogów i nauczycieli, [w:] J. Binnebesel, A. Janowicz, P. Krakowiak (red.), Jak rozmawiać z uczniami o końcu życia i wolontariacie hospicyjnym, Wydawca Via Medica, Gdańsk 2009.

22 E. Nieroba, I. Zawłocki, K. Niewiadomski, Tanatopedagogika... 
oraz na znalezienie sposobów ich popularyzacji jako elementu kształcenia ogólnego. Dzięki temu możliwe jest formowanie kompetencji nauczycieli w następujących obszarach ${ }^{23}$ :

- Poszukiwanie, gromadzenie, analizowanie i przekazywanie wiedzy, podejmowanie badań naukowych na temat cierpienia i śmierci.

Według Piotra Krakowiaka „chodzi o wiedzę na temat procesu umierania i śmierci, której posiadanie może zneutralizować lęki, obawy czy strach będące integralną częścią omawianych zagadnień" Krytyczna refleksja naukowa nad cierpieniem i śmiercią powinna uwzględnić wymiar filozoficzny, psychologiczny, teologiczny, kulturowy i społeczny tego zjawiska, opisując w ten sposób jego szeroką, ale niejednorodną perspektywę. Problemy badawcze dotyczące cierpienia i przeciwdziałania jego skutkom mogą stać się przedmiotem badań w trakcie przygotowywania prac dyplomowych wieńczących poszczególne etapy edukacji na poziomie wyższym. Styczność ze środowiskiem cierpienia w czasie studiów może podnieść kompetencje społeczne przyszłych nauczycieli.

- Prowadzenie i uczestniczenie w dyskusji na temat cierpienia i śmierci na różnych poziomach ogólności i w różnych środowiskach.

Prowadzenie dyskusji w kontekście tanatycznym daje możliwość wymiany zdań, poglądów i własnych doświadczeń. Dzięki nim wzrasta poziom świadomości społecznej, a przyszli nauczyciele mogą osobiście ustosunkować się do omawianej rzeczywistości. W tej dyskusji należy odróżnić pojęcie bólu od pojęcia cierpienia. Ból zostaje wywołany podrażnieniem zakończeń nerwowych i jest najpierw odczuwany jako ból sam w sobie, a następnie jako uczucie przykrości. By stał się on cierpieniem, niezbędna jest ocena wartościująca, podejmowana przez człowieka: „Ból jest doznawany, a cierpienie przeżywane”25. Dyskusja nad tematyką bólu i cierpienia sprawia, że te rzeczywistości przestają być tylko hipotetyczne, zwłaszcza gdy w dyskursie biorą także udział

23 P.P. Grzybowski, Praktyczne cele..., s. 8.

24 P. Krakowiak, Społeczne i edukacyjne funkcje opieki paliatywno-hospicyjnej. Badania w działaniu w latach 2002-2010, Fundacja Hospicyjna, Gdańsk 2012, s. 151.

25 J. Wicka, Ból i cierpienie - interdyscyplinarny przegląd stanowisk, „Pielęgniarstwo i Zdrowie Publiczne" 2012, nr 2(4), s. 305. 
osoby chore i cierpiące. Umiejętność prowadzenia dyskusji na tak ważne tematy jest kluczowa w podejmowaniu przez nauczycieli tematyki tanatycznej na forum klasy czy społeczności szkolnej. Dzięki niej nauczyciel „odpowiednio przygotowany w zakresie tanatopedagogiki może wzbogacić poglądy swoich uczniów na temat cierpienia i śmierci, rozszerzając treści stanowiące przedmiot potocznej refleksji, zazwyczaj opartej na przesądach i stereotypach"26.

- Udzielanie wsparcia merytorycznego osobom o niewielkiej wiedzy na temat cierpienia i śmierci oraz osobom poszukującym tej wiedzy okazjonalnie.

Wykorzystanie okazji życiowych stanowi dobrą drogę do poszerzenia wiedzy. Jeśli są one związane $\mathrm{z}$ cierpieniem, to dają możliwość udzielenia wsparcia choremu i jego bliskim. Często wsparcie to przyjmuje formę poradnictwa, które obejmuje wiele działań profilaktycznych oraz terapeutycznych zmierzających do zdiagnozowania i rozwiązywania życiowych problemów ${ }^{27}$. Wsparcie może też przyjąć formę instruktażu, mającego na celu nauczenie sposobów opieki nad chorym, przeciwdziałania trudnościom materialnym, radzenia sobie z trudnymi emocjami w żałobie czy koniecznością zastosowania modyfikacji w dotychczasowym stylu życia. Posiadanie umiejętności udzielania wsparcia osobom chorym, a także ich bliskim jest niezbędne w sytuacjach losowych, które nie omijają środowiska szkolnego. Stanowią okazje do przybliżenia i pogłębienia rozumienia tematów tanatologicznych, a także sposobów i zasad udzielania nieformalnej pomocy cierpiącym.

- Radzenie sobie z cierpieniem, chorobą oraz śmiercią w życiu własnym i bliskich.

Ta kompetencja wydaje się być najtrudniejsza ze względu na konieczność osobistego ustosunkowania się wobec choroby i śmierci. Postawa wobec śmierci posiada trzy ukierunkowania, które ją określają: postawa wobec śmierci obcego, wobec śmierci osoby bliskiej, wobec śmierci własnej ${ }^{28}$. W tych ukierunkowaniach zawarte jest stopniowa-

$\overline{26}$ E. Nieroba, I. Zawłocki, K. Niewiadomski, Tanatopedagogika..., s. 253.

27 S. Badora, B. Czeredrecka, D. Marzec, Rodzina i formy jej wspomagania, Oficyna Wydawnicza „Impuls”, Kraków 2001, s. 114.

28 A. Matuszewski, Poziom noetyczności a postawa wobec śmierci, Wydawnictwo „Bernardinum", Pelplin 2002, s. 33-34. 
nie doświadczeń, które osiągają apogeum w osobistym przeżywaniu choroby i przygotowaniu do własnej śmierci. Człowiek doświadczający w ciągu swego życia chorób i śmierci innych, powiększa zasób swych przeżyć, gdy spotyka się z chorobą i śmiercią bezpośrednio, np. stając się jej świadkiem podczas towarzyszenia bliskiej osobie w umieraniu.

Na szczęście nie każdy student pedagogiki miał osobisty kontakt ze śmiercią czy przeżywał żałobę. Powinien jednak mieć możliwość rozwijania kompetencji niezbędnych do przygotowania uczniów do radzenia sobie w sytuacjach tanatycznych. Służy temu podejmowanie osobistej refleksji nad tanatycznym wymiarem życia i ustosunkowaniem się do niego. Wymaga to posiadania umiejętności refleksyjnego myślenia, będącego „swoistym sposobem samooceny jego działania pedagogicznego, wywołującym określone zmiany w sferze wiedzy i doświadczeń zawodowych"29.

W celu sprostania tym zadaniom, niezbędne jest uwzględnienie wymiaru aksjologicznego $\mathrm{w}$ kształceniu nauczycieli. Odwołanie do wartości stanowi podstawę autorefleksji, kształtowania postaw tanatycznych i podejmowania działań pomocowych. Dlatego wciąż aktualne są słowa Kazimierza Denka:

Sytuacje edukacyjne nie są neutralne aksjologicznie. Wiążą się z określaniem preferencji i zajmowaniem stanowisk. Wymagają sądów wartościujących. Dlatego znajomość istoty, genezy, rodzajów, hierarchii określenia wartości oraz świadomość ich roli i konsekwentnej realizacji w procesie dydaktyczno-wychowawczym stanowi jedną z cech konstytutywnych tych, którzy uczą i wychowują ${ }^{30}$.

Umiejętność wartościowania oraz wdrażania w nią winna cechować osoby, które świadomie uczestniczą w edukacji, w której nie ma miejsca na epatowanie tematyką śmierci, ale jednocześnie nie jest ona wypierana, pomijana czy lekceważona.

29 J. Grzesiak, „Mentoring” $i$ „coaching” misją kompetentnego i odpowiedzialnego nauczyciela nauczycieli, [w:] J. Grzesiak (red.), Ewaluacja i innowacje w edukacji. Kompetencje i odpowiedzialność nauczyciela, Uniwersytet im. Adama Mickiewicza w Poznaniu i Państwowa Wyższa Szkoła Zawodowa w Koninie, Kalisz - Konin 2010, s. 578.

30 K. Denek, Kształcenie akademickie nauczycieli, „Nowa Szkoła” 2013, nr 1, s. 11. 


\section{Zakończenie}

Dokonując analizy znaczenia kompetencji nauczyciela, Jolanta Szempruch podkreśla, że:

najważniejszym wymiarem profesjonalnych kompetencji nauczyciela jest kategoria zmiany. Oznacza ona konieczność otwarcia się nauczyciela na twórczy rozwój i podmiotowość ucznia, na innowacje, radzenie sobie $z$ napięciami i konfliktami w szkole, ze stresem towarzyszącym odgrywaniu roli zawodowej. Otwartość na zmianę oznacza także rozumienie współczesnego świata i świadomość swego miejsca w tym świecie oraz tolerancję ${ }^{31}$.

Otwartość na zmiany - te oczekiwane z nadzieją, ale także zmiany niespodziewane, dramatyczne - zakłada gotowość sprostania generowanym przez nie wyzwaniom edukacyjnym. Skoro otwartość ta jest tak istotna $\mathrm{w}$ kształtowaniu kompetencji nauczyciela i podejmowane są kroki ku jej wdrożeniu, można żywić nadzieję, że postulat zmiany polegającej na poszerzeniu wiedzy i pogłębieniu refleksji tanatopedagogicznej przyszłych edukatorów zostanie urzeczywistniony.

Wzmocnieniem tej nadziei są dobre praktyki. Można do nich zaliczyć fakt, iż w 2019 roku Uniwersytet Papieski Jana Pawła II w Krakowie otrzymał zgodę ministra nauki i szkolnictwa wyższego na prowadzenie studiów na kierunku pedagogika, ze specjalnością tanatopedagogika ${ }^{32}$. Wydaje się, że jest to ważny krok, by uwzględnić zagadnienia tanatopedagogiczne w efektach uczenia się przyszłych nauczycieli. Warto również zauważyć inicjatywy Fundacji Hospicyjnej, a szczególnie projekt Funduszu Dzieci Osieroconych „Tumbo pomaga” ${ }^{33}$. W szerokiej ofercie pomocowej projektu jest zawarty m.in. poradnik Śmierć w społeczności szkolnej - poradnik dla nauczycieli ${ }^{34}$, zawierający praktyczne rozwiązania, wskazówki i rady skierowane do pracowników szkoły, w której

$\overline{31}$ J. Szempruch, Pedeutologia. Studium teoretyczno-pragmatyczne, Oficyna Wydawnicza „Impuls”, Kraków 2013, s. 102-103.

32 Są to pierwsze w Polsce studia pedagogiczne $\mathrm{z}$ taką specjalnością. W planach uczelni jest również powołanie studiów podyplomowych w tym zakresie.

33 Tumbo pomaga, http://www.tumbopomaga.pl (dostęp: 02.09.2019).

34 Fundacja Hospicyjna, Śmierć w społeczności szkolnej-poradnik dla nauczycieli, http://www.tumbopomaga.pl/dla-nauczycieli/smierc-w-spolecznosci-szkolnej -poradnik-dla-nauczycieli (dostęp: 02.09.2019). 
wystąpiła sytuacja tanatyczna. Poradnik jest rzetelnym wzmocnieniem wiedzy i umiejętności nauczycieli, na których spoczywa odpowiedzialność za przeprowadzenie uczniów przez trudne wydarzenia zgodnie z celami wychowawczymi.

Zapotrzebowanie na kompetencje nauczycieli jest wciąż duże, zwłaszcza na takie umiejętności, wiedzę i cechy osobowościowe, które odpowiadają aktualnym potrzebom edukacyjnym. Kształtowanie kompetencji tanatopedagogicznych jest uwarunkowane nie tylko wprowadzeniem wątków tanatologii do treści kształcenia przyszłych nauczycieli, ale także ich otwartością i gotowością zgłębiania tych niełatwych treści. Wszak wielu z nich ma z nimi styczność w życiu osobistym i w pracy. Jeśli będą umieli przyjąć w takich sytuacjach właściwe postawy, przyczynią się do rozwoju osobistego, a także ludzi wokół siebie.

\begin{abstract}
Many problems may arise in a school community. Suffering and death are one of the most significant threats which this community may face. Their consequences are painful for both students and their families. Teachers who have competences in the area of thanatopedagogy may help their students to deal with these difficult experiences. In this way, students are able to better understand inevitable experiences and the school community receives support from educators. Hence, it is necessary to include thanatical aspects in the process of educating teachers. This kind of education must have axiological references, give prospective teachers exposure to the environment of suffering, enable them to reflect, exchange opinions and experiences.
\end{abstract}

\title{
Bibliografia
}

Badora S., Czeredrecka B., Marzec D., Rodzina i formy jej wspomagania, Oficyna Wydawnicza „Impuls”, Kraków 2001.

Baruch A., Choroba nowotworowa dziecka jako czynnik powodujący zmiany $w$ funkcjonowaniu rodziny - wybrane aspekty, ,Przegląd Pedagogiczny" 2013, nr 2.

Czerepaniak-Walczak M., Kompetencja: słowo kluczowe czy „wytrych” w edukacji, „Neodidagmata” 1999, nr 24.

Denek K., Kształcenie akademickie nauczycieli, „Nowa Szkoła” 2013, nr 1.

Godawa G., Funkcjonowanie rodziny dziecka objętego domowq opiekq hospicyjną. Studium tanatopedagogiczne, Wydawnictwo Akapit, Toruń 2016. 
Godawa G., Rodzina wobec nieuleczalnej choroby dziecka. Aspekty tanatopedagogiczne, Oficyna Wydawnicza „Impuls”, Kraków 2018.

Grzesiak J., „Mentoring” $i$ „coaching” misja kompetentnego i odpowiedzialnego nauczyciela nauczycieli, [w:] J. Grzesiak (red.), Ewaluacja $i$ innowacje w edukacji. Kompetencje i odpowiedzialność nauczyciela, Uniwersytet im. Adama Mickiewicza w Poznaniu i Państwowa Wyższa Szkoła Zawodowa w Koninie, Kalisz - Konin 2010.

Grzybowski P.P., Praktyczne cele $i$ aspekty kształcenia tanatologicznego pedagogów i nauczycieli, [w:] J. Binnebesel, A. Janowicz, P. Krakowiak (red.), Jak rozmawiać z uczniami o końcu życia i wolontariacie hospicyjnym, Wydawca Via Medica, Gdańsk 2009.

Grzybowski P.P., Chorzy i umierajacy jako Obcy. Wspólne wątki pedagogiki międzykulturowej $i$ tanatopedagogiki, [w:] T. Lewowicki, E. Ogrodzka-Mazur (red.), Edukacja międzykulturowa - teorie, poglądy, doświadczenia społeczne, Wydawnictwo Adam Marszałek, Cieszyn - Warszawa - Toruń 2010.

Konieczna-Kucharska M., Miękkie i twarde kompetencje nauczycieli, „Zeszyty Naukowe Politechniki Częstochowskiej - Zarządzanie” 2015, nr 19.

Košč S., Pedagogika wobec wyzwań współczesności. Człowiek - wartości-wychowanie, [w:] E. Włodek, A. Mirski (red.), Pedagogika wobec wyzwań współczesności. Człowiek - wartości-wychowanie, Wydawnictwo Akademia Ignatianum w Krakowie, Kraków 2016.

Krakowiak P., Społeczne i edukacyjne funkcje opieki paliatywno-hospicyjnej. Badania w działaniu w latach 2002-2010, Fundacja Hospicyjna, Gdańsk 2012.

Kwaśnica R., Wprowadzenie do myślenia o nauczycielu, [w:] Z. Kwieciński, B. Śliwerski (red.), Pedagogika. Podręcznik akademicki, t. 2, PWN, Warszawa 2004.

Kwiasowski Z., Cenda-Miedzińska K. (red.), Edukacja dla bezpieczeństwa wobec wyzwań współczesności, Wydawnictwo Uniwersytetu Pedagogicznego w Krakowie, Kraków 2012.

Kwiecińska A., Wybrane zagadnienia z tanatologii, [w:] K. de WaldenGałuszko, A. Kaptacz (red.), Pielęgniarstwo w opiece paliatywnej i hospicyjnej, PZWL, Warszawa 2008.

Mastalski J., Aksjologiczne wymiary kompetencji nauczyciela w kontekście współczesnych wyzwań cywilizacyjnych, [w:] J. Grzesiak (red.), Ewaluacje $i$ innowacje w edukacji. Kompetencje $i$ odpowiedzialność nauczyciela, Uniwersytet im. Adama Mickiewicza w Poznaniu i Państwowa Wyższa Szkoła Zawodowa w Koninie, Kalisz - Konin 2010.

Matuszewski A., Poziom noetyczności a postawa wobec śmierci, Wydawnictwo „Bernardinum”, Pelplin 2002. 
Nieroba E., Zawłocki I., Niewiadomski K., Tanatopedagogika w procesie kształcenia nauczycieli, „Edukacja-Technika-Informatyka” 2010, nr 1.

Okoń W., Nowy słownik pedagogiczny, Wydawnictwo Akademickie Żak, Warszawa 2004.

Piorunek M., Werner I., (Nie)wspierajacy wychowawca klasy. Realizacja pomocowych aspektów roli nauczyciela z perspektywy gimnazjalistów, [w:] S.T. Kwiatkowski, D. Walczak (red.), Kompetencje interpersonalne $w$ procesie edukacji, Wydawnictwo Akademii Pedagogiki Specjalnej, Warszawa 2017.

Strykowski W., Kompetencje współczesnego nauczyciela, „Neodidagmata" 2005, nr 27/28.

Szempruch J., Pedeutologia. Studium teoretyczno-pragmatyczne, Oficyna Wydawnicza „Impuls”, Kraków 2013.

Wicka J., Ból i cierpienie - interdyscyplinarny przegląd stanowisk, „Pielęgniarstwo i Zdrowie Publiczne" 2012, nr 2(4).

Zakowicz I., Tanatyczny tryptyk ponowoczesności: kryzys, pornografia i renesans śmierci, „Ogrody Nauk i Sztuk” 2011, nr 1.

Żeber-Dzikowska I., Wysocka-Kunisz M., Szydłowska A., Kompetencje nauczyciela w kontekście kształcenia, „Społeczeństwo. Edukacja. Język" 2016, nr 4.

\section{Netografia}

Ablewicz K., Recenzja rozprawy doktorskiej p. mgr Justyny Sztobryn-Bochomulskiej pt.: Tanatos w literaturze dziecięcej i jego pedagogiczny wymiar (s. 295) napisanej pod kierunkiem dr hab. prof. UŁ Anny Walczak, http://wnow.uni.lodz.pl/wp-content/doc/doktoraty/Recenzja2_JustynaSztobryn.pdf (dostęp: 30.08.2019).

Fundacja Hospicyjna, Śmierć w społeczności szkolnej - poradnik dla nauczycieli, http://www.tumbopomaga.pl/dla-nauczycieli/smierc-w-spolecznosci-szkolnej-poradnik-dla-nauczycieli (dostęp: 02.09.2019).

Tumbo pomaga, http://www.tumbopomaga.pl (dostęp: 02.09.2019). 